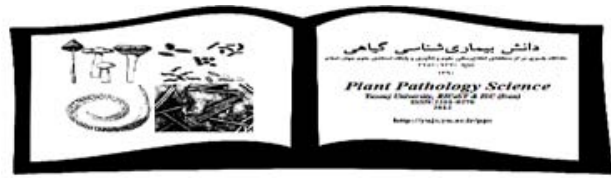

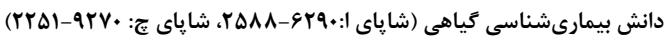

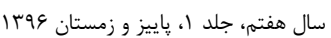

Plant Pathology Science (eISSN:2588-6290, pISSN:2251-9270) Vol. 7(1), 2018

\title{
Mycoviruses Application in Biocontrol of Fugal Pathogens
}

MUSA MOHAMMADI, AHMAD HOSSEINI ${ }^{\bowtie}$, EBRAHIM SEDAGHATI and SAMIN HOSSEINI

Department of Plant Protection, Vali-e-Asr University of Rafsanjan, Iran

( $\square$ Corresponding author: Hosseini@vru.ac.ir)

Received: 30.01 .2017

Accepted: 28.08.2017

Mohammadi M., Hosseini A., Sedaghati E. and Hosseini S. 2018. Mycoviruses application in biocontrol of fugal pathogens. Plant Pathology Science 7(1):51-62.

Abstract : Mycoviruses or fungal parasitic viruses have dsDNA, dsRNA or ssRNA genome. Some of these viruses have a restricted host range and can infect certain strains of host species. In contrast, some other viruses have wider host range and can infect different species of a fungal family. In most cases these viruses are transmitted by anastomosis of mycelium. In a phenomenon called hypovirulence, most of these viruses decrease the virulence of their host fungus. Discovery of hypovirulence revealed the biocontrol ability of mycoviruses. In summary, mycoviruses could be implemented as powerful agents for biocontrol of fungal pathogens and induction of resistance in plants.

Key words: Hypovirulence, Sclerotinia, Penicillium, Cryphonectria

$$
\begin{aligned}
& \text { كاربرد ميكوويروسها در مهار زيستى قارجهاى بيماركر }
\end{aligned}
$$

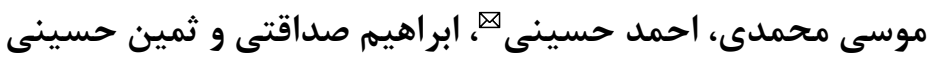

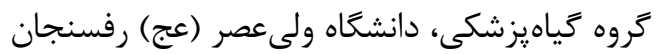

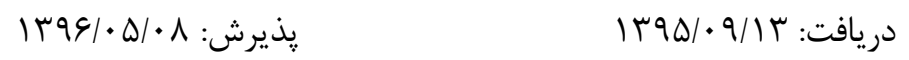

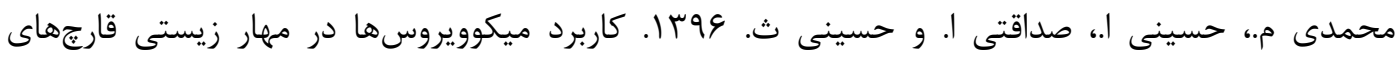

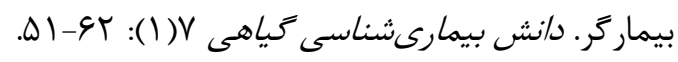

مقدمه

بيمارى اقتصـادى مهمسى از روى قـارج 1946 Agaricus bisporus (Lange) Imbach، بـا نشـانههـاى

بدشكلى اندامهاى بارده و كاهش شديد محصول، در سالنهاى يرورش قارج برادران La France در پرنسيلوانيا

هـئول مكاتبه: Hosseini@vru.ac.ir 


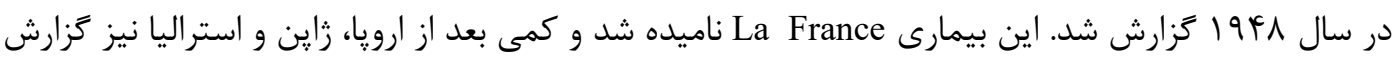

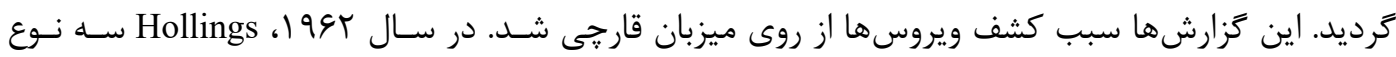
״يكره ويروسى را از روى اين قارج جداسازى نمود. اين اولين گزارش از يِيكره ويروسها در قارج و تولدى براى ويروس شناسى قارجى بود. نشانههاى ايجادشده توسط اين ويروسها بسيار متغيـر اسـت، بعضى نشـانههـاى شديدى را بر روى قارج ميزبان خود ايجاد مى كنند، برخى بدون نشانه هسـتند، بعضى باعث كـاهش قـدرت بيمارىزايى قارجهستند (Hypovirulence) و بعضى نيز باعث افزايش بيمارىزايى (Hypervirulence) ميزبان خود مىشوند (Ghabrial and Suzuki 2009). امروزه ميكوويروسها از قارجهاى مختلفى جداسازى شـدهانـد بلهورى كه بيش از • لم ميكوويروس توالى يابى و در بانك زن NCBI ثبـتشـده اسـت. بـيش از نـيمقــرن از كشف اولين ميكوويروس گذشته است، ولى اين ويروسها به علت اهميت آنها در مهار زيسـتى بيمارگرهـاى

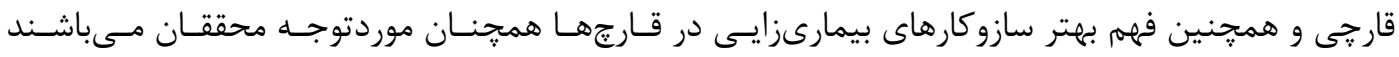

.(Xie and Jiang 2014)

اكثر ميكوويروس ها، بهجز Rhizidiomyces virus كـه داراى زنـوم dsDNA اسـت، داراى زنـوم RNA

دو رشتهاى هستند. تا ِيشازاين هيج كَزارشى از ويروسها SsRNA- وجود نداشت اما اخيراً اين نوع زنوم براى ويروسى با نـام 1 SsNSRV-1) Sclerotinia sclerotiorum negative-stranded RNA virus $َ$ كـزارش شـده است (Liu et al. 2014). تاكنون ويروسهايى با زنوم DNA تك رشته در قارجها شناسايى نشـدهانـد. در ايـن بين rا تيره براى ميكوويروس هايى با زنوم RNA شناسايىشده است (Ghabrial and Suzuki 2009). اعضاى

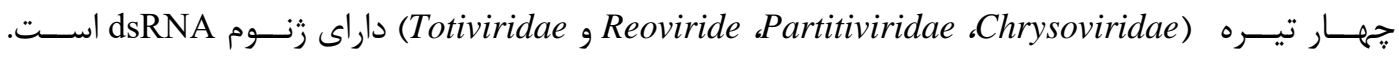
Totiviridae داراى يك قطعه رنوم و سه تيره ديكر داراى جند قطعه زنوم هسـتند. زنـوم ايسن ويـروسهـا در Aoki et al. 2009, Chiba et al. 2009, Liu et al. 2009, Xie et al. ) داخل يوشش يروتيينى قرار مى

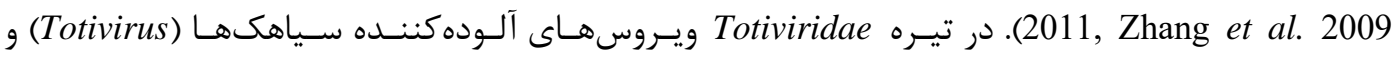
Ghabrial and Nibert ( كه انكَل قارجهاى رشـتهاى هسـتند، حضـور دارنـــ Victorivirus 2009). تيره Chrysoviridae داراى يك جنس است (Chrysovirus) كـه Penicillium chrysogenum virus 
بهعنوان گونه تيب شناخته مىشود (PcV) تيره Partitiviridae شرح دادهشه است كه فقط جنس Partitivirus ويروسهاى آلوده كننده قارجها را دربـر مى گيرد (fungal partitiviruses) (Regenmortel and Mahy 2009, Tavantzis 2008). اعضـاى شـش تيـره وHypoviridae ،Gammaflexiviridae ‘Endornaviridae ‘Barnaviride Alphaflexiviridae Narnaviridae (Gammaflexiviridae مشخصى را تشكيل نمى دهند. دو تيره Metaviridae و Pseudoviridae داراى زنوم RNA با رونوشت بـردارى Aoki et al. 2009, Chiba et al. 2009, Liu et al. 2009, Xie et al. 2011, Zhang et al. ) معكوس هستند,

\section{r - دامنه ميزبانى ميكوويروسها}

ييشتر تصور بر آن بود كه ميكوويروسها دامنه ميزبانى محدودى داشته و فقط روى قـارجهـاى داراى

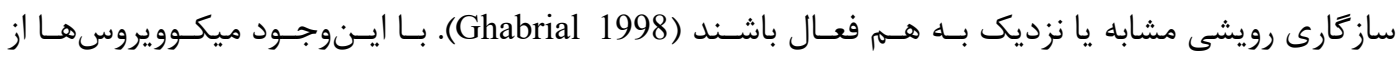
ويروسهاى ديخر جانداران متفاوت نيستند و احتمالاً دامنه ميزبانى مختلفى دارنـد. تحقيقـات جديـد صـورت گرفته نشان داده است كه دامنه ميزبانى اين ويروسها فراتر از گونههاى با سازگًارى رويشى است و حتى بـين جنس هاى مختلف قارجى نيز مى توانند فعاليت داشته باشند. بـراى مثـال Mycoreovirus 1 توانـايى تكثيــر و تغيير فنوتيب در گونه Cryphonectria parasitica (Murrill) Barr 1978 با سازگًارى رويشى مختلف راى دارد. علاوه بر آن سويه EP713 از Cryphonectria hypovirus 1 مىتواند روى جــس هـاى مختلـف قـارجى Endothia gyrosa و و همجنين ميزبان طبيعـى آن C. palsa ceratosperma، باعـث كـمآزارى

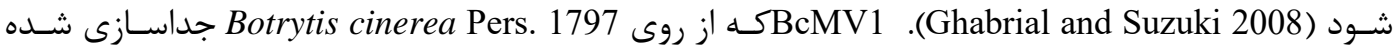

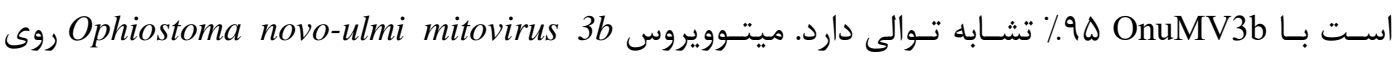
فعاليت دارد. علاوه بر آن Ophiostoma mitovirus 3a كه از جنس Mitovirus مىباشـد نيـز از روى Sclerotinia homoeocarpa Benn. 1937 كشف شـده اسـت. بـه علـت رابطـه دور فيلـوزنتيكى بــين و Botrytis با جنس Ophiostoma مي توان به دامنـه ميزبـانى وسـيع ايـن ويـروسهـا يسى بـرد 


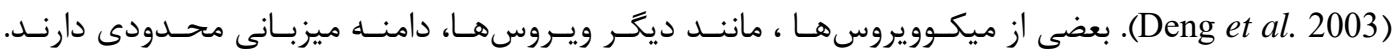
توانايى آلوده سازى برخى گونههاى Sclerotinia را دارد ولى روى B. cinerea و برخى ديخـر از SsHADV-1 قارجها مانند Coniothyrium minitans Campb. 1947 نمى تواند فعاليـت كنـد. جـون دو جـنس Botrytis و Sclerotinia

.(Yu et al. 2013)

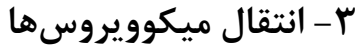

ميكوويروسها فاقد مراحل زندگى خارج سلولى هستند. تاكنون هيج ناقلى براى ايسن نـوع ويـروسهـا شناسايى نشده است، با اينوجود محققان معتقدند كه بايد ناقلى براى اين ويروسها وجود داشته باشد. بهطور كلى براى اين ويروسها دو نوع انتقال در نظر گرفته مىشود، انتقال از نسلى به نسل ديگر كه انتقال عمـودى نام دارد و انتقال به ميزبانهاى جديد كه به آن انتقال افقى كفتـه مسىشـود (Pearson et al. 2009). انتقـال عمودى ميكوويروس ها توسط هاكَها بهخصوص هاكَهاى غيرجنسى قارجهاى ميزبان مسىيابنـد. بايـد توجــه داشت كه ممكن است اين ويروسها در طى توليـدمثل جنسـى از بـين برونـد. بـا ايـنوجـود در جــسـهـاى Narnaviruses و Totiviruses توليدمثل جنسى اغلب قارجهاى آسكوميستى از بين ميروند، در حالى كه توسط بازيديوسيورها معمولاً بهطـور مؤثرى انتقال مىيابند. بنابراين كيفيت انتقال در طى توليدمثل جنسى كاملاً به قارج ميزبان ويـروس بسـتخى دارد. انتقال افقى آنها توسط يِيوند ريسهها و معمولاً فقط در بين كَونهاى يـك جـنس كـه داراى سـازكَارى رويشى هستند صورت مى گيرد. در هنَام تماس ريسههاى آلوده با ريسه فاقد ويروس، ممكن است ياسخهـاى ناساز گارى رخ دهد، در صورت ايجاد ياسخهاى ناساز گارى مرگ برنامهريزىشده سلولها معمولاً باعث محـدود شدن انتقال مىشود (Choi et al. 2012, Chun and Lee 1997, Ghabrial and Suzuki 2008).

\section{r- ( كم آزارى و مبارزه زيستى}

ميكوويروس هايى كه تاكنون بيشترين مطالعه روى آنها صورت گرفته است، باعث سه نوع نشانه در

ميزبان خود مىشوند: ( ) فنوتيٍ كشنده، (r) كم آزارى، (r) تضعيف يا كاهش رشد. سيستم كشنده شامل 
توتى ويروسها وdsRNAs اقمارى همراه آن است. اين سيستم باعث كد شدن يروتيينى مىشـود كـه ترشـح آن توسط ميزبان، از بين رفـتن قـارجهـاى مشـابه فاقـد ايـن سيسـتم ويروسـى را در يسى دارد ( Alfen and Saccharomyces cerevisiae (Kazmierczak 2008 بهترين مثال براى اين سيسته كشنده در مخمــر نـان 1838 قارجهاى بيماركر گياهى رخ مىدهد كه آن را كم آزارى مىنامند. بلطور كلى هر عاملى كه سبب كاهش قدرت رشد وتكثير طبيعى قارج بيماركر شود از بيمارىزايى آن مى كاهد(Alfen and Kazmierczak 2008). در سال ا 19 1، براى اولين بار يديده كم آزارى را كشف نمود. وى متوجه شد كه در ايتاليا برخى از درختـان شاهبلوط آلوده به Cryphonectria parasitica، برخلاف ديكر درختان دجار يزمردگى كامل نشدهانـد. ريسـهـ قارج به لايه خارجى يوست محدودشده و سبب گسترش سطحى شانكر شده بود. به دنبال آن در سال 1994، جrente جدايههايى از C. parasitica را از روى شانكرهاى در حال بهبود جـــا نمـود. وى مشـاهده كـرد كـــ هاكزايى و توليد رنخدانه در اين جدايهها كمتر از جدايههاى معمولى است. اين جدايهها بعد از مايهزنسى بـهـ شاهبلوط از خود بيمارىزايى كمى نشان دادند. در قدم بعد اين جدايهها به درختان بيمار با جدايه بيمـارىزاى معمولى مايهزنى شدند، نتيجه حاصله بسيار قابل توجه بود، شـانكرهاى روى شـاخه شـروع بــه بهبــود كردنـد. Grente اين يديده را كم آزارى ناميد. جدايههاى كم آزار با انتقال dsRNA در طى ييوند ريسها باعث كاهش قدرت بيمارىزايى جدايههاى بيمارىزا مىشوند. اين يديده اساس مبارزه زيستى توسط ميكوويروسهـا را بنـا نهاد (Heiniger and Rigling 1994). در سال Anagnostakis 1919 مرورى بر يزوهشهـاى خـود در مـورد امكان فعاليت مبارزه زيستى به كمك اين ويروس با بيمارى سوختكى شاهبلوط را منتشر ساخت و بيان نمـود در صورت يافتن راهى براى انتشار جدايههاى كمآزار قارج بيماركر امكان حفاظـت درختـان شـاهبلـوط از ايـن بيمارى قارجى مخرب ممكن خواهد بود. برنامه مبارزه زيستى در ارويا (فرانسـه، سـوييس، ايتاليـا) بـهوسـيله استقرار طبيعى جدايههاى كم آزار قارج بيماركر بهخوبى اجرا شد. در آمريكا نيز به اميد دستيـابى بـه نتـايج مشابه برنامه مبارزه زيستى توسط اين ميكـوويروس بــه اجـرا درآمـد. در سـال \& +. T، Milgroom و Cortesi كزارش تحليلى مهمى را در رابطه با اين روش مبارزه زيستى منتشر كردند، بر اساس آن بهجـز جنــد اسـتثنا، مبارزه زيستى تقريباً در تمام شمال شرق آمريكا با شكست مواجه شده بود (Milgroom and Cortesi 2004). 
عوامل مختلفى به علت شكست اين طرح مبارزه زيستى نسبت داده شد، ولى در بين آنها عـدم انتقـال افقىى كار آمد توجه بيشترى را به خود جلب كرد، زيرا در آمريكا گروههاى رويشى مختلفى از قارج مـوردنظر حضـور دارد و عدم سازكارى رويشى از انتقال افقى جلوكيرى مى كند ولى در ارويا به دليل حضور جدايههاى محدود و انتقال افقى موفقيتآميز اين طرح بهخوبى اجرا شد (Milgroom and Cortesi 2004). از ديخــ بيمـارىهـاى

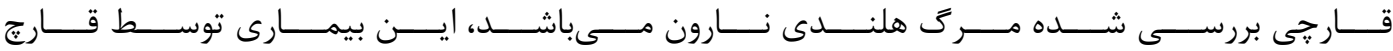
Ophiostoma ulmi (Buisman) Nannf. 1934 مبارزه زيستى اين قارج بيماركر با استفاده از ميكوويروسها توسط محققــان متعـددى يِيشـنهاد شـده اسـت. ميكوويروسهاى آلودهننده اين قارج باعث كاهش قابليت آلوده سازى گياهان سالم و همجنين كاهش توليـد هاگ مىشوند (Webber et al. 1993, Brasier 2000). ميكوويروسهاى متعددى در محيط آزمايشأهى براى كنترل اين بيمارى مورد بررسى قرار كرفته است كه يراستفادهترين آنها ويروسهـاى D-Factor اسـت، ايـن ويروس ها با ساختار dsRNA شناخته مىشوند و يزوهشها نشان دادهاند كه آلودىى قارج عامل بيمارى به اين ميكوويروسها باعث بهبود زخمهاى ايجاد شده روى درخت مسىشـود (Ganely and Bulman 2016). تعـداد زيادى از مخروطيان (عمدتاً Picea، Pinus، و Abies) در اروياى شمالى و مركزى، آمريكـاى شـمالى و زاين توسط قارج 1969 Gremmeniella abietina (Lagerb.) Morelet آلوده مىشوند. ايـن بيمـاركر گيـاهى باعث ايجاد شانكر ساقه و همجنــين سرخشـكيدگى شـاخههـا مسىشـود (Botela et al. 2010). سـه تيـره از ميكوويروسهاى dsRNA از اين بيمارگر گياهى جداسازى شدهاند: Gremmeniella abietina mitocondrial GaRV-L1, ) Gremmeniella abietina RNA virus L1 ،(GaMRV-S1, Narnaviridae) RNA virus S1

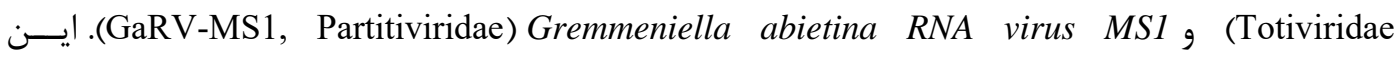
ميكوويروسها بسيار شايع بوده و در 9 درصد جدايههاى اسيانيايى و •له درصد جدايههاى تركيـه شناسـيى شده است (Aday et al. 2012). در اسيانيا تنها توليدمثل غيرجنسى قـارج مـوردنظر گَزارش شـده اسـت و جمعيت بالايى از ميكوويروسهاى ذكرشده در اسيانيا يافت مىشود، به نظر مىرسد توليدمثل غيرجنسى در انتقال و گسترش اين ميكوويروسها بسيار اهميت داشته باشد (Muñoz-Adalia et al. 2016). با وجود آنكـهـ امروزه استفاده از ميكوويروسها بهعنوان عوامل مبارزه زيستى برخى بيمارىهاى درختان جنگلى متداول شده 
است، گزارشهاى محدودى در رابطه با استفاده از اين ويروسها در زمينهاى زراعى عليه بيمارىهاى قـارجى وجود دارد. البته در رابطه با B. cinerea مطالعات متعددى صورت كفته و تعداد زيادى ميكـوويروس بــــنـوم RNA از آن جداسازى شده اسـت (Gammaflexiviridae، Totiviridae،Narnaviridae،Alphaflexiviridae، Partitiviridae و Partitiviridae ميكوويروس ها باعث كاهش بيمارىزايى آن مىشود. ولى در مورد B. cinerea نيز عـدم سـازكارى رويشى از عمدترين مشكلات پيشرو براى مبارزه زيستى توسط ميكوويروسها مىباشـد (Wu et al. 2016). بـه دليـل تفاوت در نوع اكوسيستم موجود در مزارع و جنكَلها، براى مثال تـراكم بـالاى كياهـان زارعى، تنـوع يـايين كَنهها و شرايط محيطى يكنواخت مزارع باعث تسهيل رشد، توليدمثل و انتقال بيمارگرهاى گياهى مىشـوند. البته اين ويزگگىها مى تواند به استقرار و بازدارندگى ميكوويروسها نيز كمك كند. اخر بتوانيم جدايههاى آلوده به ميكوويروسها را در زمان و ميزان مناسب در مزرعه استفاده نماييم كمك زيادى به استقرار ميكوويروسهـا و جدايههاى آلوده به آنها خواهد كرد. اجراى اين نـوع مبــارزه زيسـتى سـختىهـايى را نيـز خواهــد داشـت. كشاورزان هميشه نيازمند روشهايى هستند كه در كمترين زمان ممكن بيمارى كياهى آنها را كنترل نمايد. در صورت استفاده از ميكوويروسها در مزرعه، زمان موردنياز براى استقرار آنها روى گياه بسيار اهميت دارد، ولى به نظر مىرسد مسئله عدم سازگًارى رويشى كه از انتقال مؤثر اين ويروسها جلوكيرى مسى كنـد يكى از عمدهرين مشكلات يِش روى جنين روشى است. در مطالعهاى، قطعات ريسه جدايه كمآزار Ep-1PN (آلـوده Sclerotinia sclerotiorum از قـارج (Sclerotinia sclerotiorum debilitation-associated RNA virus بـ Ep-1PN در مزرعه كلزا محلولياشى شده است، سـيس جدايـهاى از بيمـاركَر كـهـــا بـ (Lib.) de Bary 1884 سازگارى رويشى ندارد در گَياهان مايهزنى شدند. تمام كَياهان توسط جدايه بيمـاركر از بـين رفتــد. ولى در مايهزنى مزرعهاى با جدايههاى داراى سازكارى رويشى مشابه Ep-1PN، مبارزه زيستى با موفقيت حاصل شـد (Xie and Jiang 2014). براى رفع جنين مشكلاتى كه ناشى از عدم انتقال مؤثر در گروههاى رويشى مختلـف است مى توان برنامههاى مختلفى را اجرا نمود. همان طور كه قبلاً نيز اشاره شد عدم سـازعارى رويشى باعـث مرك برنامهريـزىشـده سـلول (PCD يـا Programed Cell Death) شـده و درنتيجــه انتقـال افقـى صـورت نمى گيرد. استفاده از مواد شيميايى براى تحت تأثير قرار دادن PCD و يا غيرفعال كـردن آن مسىتوانـد باعـث 
انتقال مؤثر اين ويروسها شود. يُوهشهاى صورت كَفته حاكى از آن است كه تركيبات فلـزى روى بـهــور مؤثرى مى تواند باعث تضعيف PCD در جدايههاى فاقد ساز كارى رويشى شوند. در يكى از ايـن مطالعـات دو كروه رويشى مختلـف از قـارج Rosellinia necatrix Berl. ex Prill. 1904 روى محسيط كشت مشـترى كـه داراى تركيبات روى است رشد داده شدند، بيوند ريسه بين دو جدايه بسيار بهبوديافته و ميكوويروس بهراحتى بين دو جدايه منتقل شد (Hutchison و همكاران در بررسىهـاى خـود نشـان دادهاند كه كَونهاى فعال اكسيرن (ROS) نقش مؤثرى در فرآيند PCD داشته و در صـورت اقتصـادى بـودن مىتوان از آن براى كنترل PCD بهره برد (Hutchison et al. 2005). اين كزارشها نشان مىدهد كه مطالسه. بيشتر روى سازوكارهاى PCD و عوامل كنترل كننده آن مىتواند به نتايج اميدواركنندهاى را در رابطه بـا رفع مشكل عدم سازكًارى رويشى و در نتيجه مبارزه زيستى موفق توسط ميكوويروسها منجـر شـود. روش ديخـر براى حل مشكل انتقال ويروسها يافتن ناقل براى آنها است. با وجود آنكه تاكنون ناقلى براى ميكوويروسهـا يافت نشده است، در صورت يافتن ناقل براى اين ويروسها مىتوان بهطور مؤثرى مشكل ناساز كارى رويشى در انتقال آنها را رفع نمود. كزارش شده كه احتمالاً برخى از ميكوويروسها توانـايى انتقـال افقـى بـدون ييونـــ

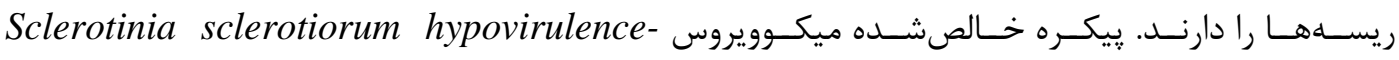
1, S. sclerotiorum توانايى آلـوده سـازى ميزبـان خـود، SsHADV-1) associated DNA virus 1 بلهورت خارج سلولى دارد. يِيكرههاى خـالصشـده بـهـراحتـى ميزبـان خـود را روى محـيط كشت PDA و

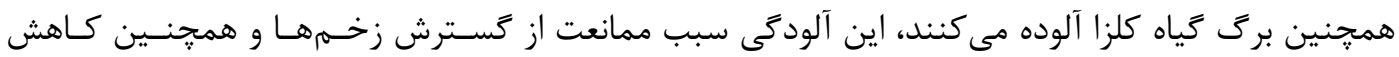
قدرت بيمارىزايى قارج بيماركر مىشود (Yu et al. 2013).

\section{نتيجه كيرى و ييشنهاد}

در ابتداى كشف ويروسها از بافت ميزبان قارجى، خسـارت اقتصـادى آن در سـالنهـاى كشـت قـارج

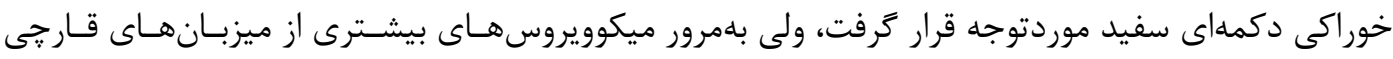
ديكر و بخصوص از قارجهاى بيماركر جداسازى شدند و بهدنبال آن قابليت مبارزه زيستى اين ويروسها توجـهـ بيشترى را به خود جلب نمود. نمونه موفق مبارزه زيستى توسط اين ويروسها در ارويا، بيمارىشناسان گياهى را بسيار اميدوارتر كرد. بررسىهاى انجامشده نشان داده است كه اصلىترين مشكل يیش رو بـراى استفاده از 
اين ويروسها عدم ساز كارى رويشى در جدايههاى مختلف قارجى براى انتقال افقى آنها است. با اين وجود در

صورت غلبه بر اين مشكل، عامل مهار زيستى بسيار كارآمدى را عليه بيماركرهاى قـارجى در اختيـار خـواهيم

داشت زيرا استفاده از ميكوويروس ها در مهار اين بيماركرها مزاياى ويزٔهاى خواهـــ داشـت. بـراى مثـال، ايـنـ

ويروس ها مىتوانند بلهور قابلتوجه از گَترش زخممها و لكهها توسط بيماركرهاى قارجى جلـوگيرى نماينــد

زيرا آنها تمايل زيادى به رسيدن به مناطق فعال رشدى قارج براى تكثير خود رادارنـد (Boine et al. 2012).

البته رشد جدايههاى كمآزار قارجى روى ميزبان خود مىتواند سبب توليد الكوهاى مولكولى مرتبط با بيمارگر

يا ييـامهــاى قابـلرديـابى توسـط ميزبـان شـوند. (PAMPs =Pathogen Associated Molecular Patterns)

شناسايى اين الخوهاى مولكولى و ييامها باعث بروز مقاومت القايى در كياهان خواهد شـد، در نتيجـهـ كيـاه در

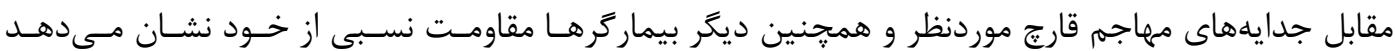

(Xie and Jiang 2014)، بنابر اين با استفاده از جدايههاى كمهزآ علاوه بر كنتــرل مسـتقيهم بيمـارگر، بـهـــور غيرمستقيم نيز با القاى مقاومت در گياهان مىتوان سبب مهار و يا كاهش شدت بيمارى شد.

\section{References}

1. Alfen N. K. V. and Kazmierczak P. 2008. Hypovirulence. Pp. 574-580. In: B. W. J. Mahy and M. H. V. V. Regenmortel(ed). Encyclopedia of Virology. Academic Press, USA .

2. Aoki N., Moriyama H., Kodama M., Arie T., Teraoka T. and Fukuhara T. 2009. A novel mycovirus associated with four double-stranded RNAs affects host fungal growth in Alternaria alternata. Virus Research 140:179-187.

3. Boine B., Kingston R. L. and Pearson M. N. 2012. Recombinant expression of the coat protein of Botrytis virus $X$ and development of an immunofluorescence detection method to study its intracellular distribution in Botrytis cinerea. Journal of General Virology 93:25022511 .

4. Botella L., Tuomivirta T. T., Kaitera J., Carrasco Navarro V., Diez J. J., and Hantula J. 2010. Spanish population of Gremmeniella abietina is genetically unique but related to type A in Europe. Fungal Biology 114:778-789.

5. Brasier C. M. 2000. Viruses as biological control agents of the Dutch elm disease fungus Ophiostoma novo-ulmi. Pp. 201-212. In: C.P. Dunne (ed.). The Elms: Breeding, Conservation and Disease Management. Kluwer Academic Publishers, USA. 
6. Chiba S., Salaipeth L., Lin Y.-H., Sasaki A., Kanematsu S. and Suzuki N. 2009. A novel bipartite double-stranded RNA mycovirus from the white root rot fungus Rosellinia necatrix: molecular and biological characterization, taxonomic considerations, and potential for biological control. Journal of Virology 83:12801-12812.

7. Choi G. H., Dawe A. L., Churbanov A., Smith M. L ,.Milgroom M. G. and Nuss D. L. 2012. Molecular characterization of vegetative incompatibility genes that restrict hypovirus transmission in the chestnut blight fungus Cryphonectria parasitica. Genetics 190:113-127.

8. Chun S. J. and Lee Y. H. 1997. Inheritance of dsRNAs in the rice blast fungus, Magnaporthe grisea. FEMS Microbiology Letters 148:159-162.

9. Deng F., Xu R. and Boland G. 2003. Hypovirulence-associated double-stranded RNA from Sclerotinia homoeocarpa is conspecific with Ophiostoma novo-ulmi mitovirus 3a-Ld. Phytopathology 93:1407-1414.

10.Ganley, R. J., and L. S. Bulman. 2016. Dutch elm disease in New Zealand: impacts from eradication and management programmes. Plant Pathology 65:1047-1055.

11.Ghabrial S. A. 1998. Origin, adaptation and evolutionary pathways of fungal viruses. Virus Genes 16:119-131.

12.Ghabrial S. A. and Suzuki N. 2008. Fungal Viruses. Pp. 284-291. In: B. W. J. Mahy and M. H. V. v. Regenmortel(ed) .Encyclopedia of Virology. Academic Press, USA.

13. Ghabrial S. A. and Nibert M. L. 2009. Victorivirus, a new genus of fungal viruses in the family Totiviridae. Archives of Virology 154:373-379.

14.Ghabrial S. A. and Suzuki N. 2009. Viruses of plant pathogenic fungi. Annual Review of Phytopathology 47:353-384.

15.Heiniger U. and Rigling D. 1994. Biological control of chestnut blight in Europe. Annual Review of Phytopathology 32:581-599.

16.Hutchison E., Brown S., Tian C. and Glass NL. 2005. Transcriptional profiling and functional analysis of heterokaryon incompatibility in Neurospora crassa reveals that reactive oxygen species, but not metacaspases, are associated with programmed cell death. Microbiology 155:3957-3970. 
17.Ikeda K., Inoue K., Kida C., Uwamori T., Sasaki A., Kanematsu S. and Park P. 2013. Potentiation of mycovirus transmission by zinc compounds via attenuation of heterogenic incompatibility in Rosellinia necatrix. Applied and Environmental Microbiology 79:36843691.

18.King A. M., Adams M. J., Lefkowitz E. J. and Carstens E. B. 2012. Virus Taxonomy: Classification and Nomenclature of Viruses. Elsevier, USA, 1272p.

19.Liu H., Fu Y., Jiang D., Li G., Xie J., Peng Y., Yi X. and Ghabrial S. A. 2009. A novel mycovirus that is related to the human pathogen hepatitis $\mathrm{E}$ virus and rubi-like viruses. Journal of Virology 83:1981-1991.

20.Liu L., Xie J., Cheng J., Fu Y., Li G., Yi X. and Jiang D. 2014. Fungal negative-stranded RNA virus that is related to Bornaviruses and Nyaviruses. Proceedings of the National Academy of Sciences 111:12205-12210.

21.Milgroom M. G. and Cortesi P. 2004. Biological control of chestnut blight with hypovirulence: a critical analysis. Annual review of phytopathology 42:311-338.

22.Muñoz-Adalia E. J., Fernández M. M. and Diez J. J. 2016. The use of mycoviruses in the control of forest diseases. Biocontrol Science and Technology 26:577-604.

23.Pearson M. N., Beever R. E., Boine B., Arthur K. 2009. Mycoviruses of filamentous fungi and their relevance to plant pathology. Molecular Plant Pathology 10:115-128.

24.Regenmortel M. H. and Mahy B. W. 2009. Desk Encyclopedia of Plant and Fungal Virology. Academic Press, USA, 613p.

25.Tavantzis S. 2008. Partitiviruses of fungi. Pp. 63-68. In: B. W. J. Mahy and M. H. V. Regenmortel(ed). Encyclopedia of Virology. Academic Press, USA.

26. Webber J. F., Sticklen M. B. and Sherald J. L. 1993. D factors and their potential for controlling Dutch elm disease. Pp. 322-332. In: M. B. Sticklen, J. L. Sherald (ed.). Dutch Elm Disease Research: Cellular and Molecular Approaches. Springer, USA.

27.Wickner R. B. 1996. Double-stranded RNA viruses of Saccharomyces cerevisiae. Microbiological Reviews 60:250.

28.Wu M., Zhang J., Yang L. and Li G. 2016. RNA mycoviruses and their role in Botrytis biology. Pp. 71-90. In: S. Fillinger, Y. Elad (ed.). Botrytis-the Fungus, the Pathogen and its Management in Agricultural Systems. Springer International Publishing, Switzerland. 
29.Xie J., Xiao X., Fu Y., Liu H., Cheng J., Ghabrial S. A., Li G. and Jiang D. 2011. A novel mycovirus closely related to hypoviruses that infects the plant pathogenic fungus Sclerotinia sclerotiorum. Virology 418:49-56.

30.Xie J. and Jiang D. 2014. New insights into mycoviruses and exploration for biological control of crop fungal diseases. Annual Review of Phytopathology 52:45-68.

31.Yu X., Li B., Fu Y., Xie J., Cheng J., Ghabrial S. A., Li G., Yi X. and Jiang D. 2013. Extracellular transmission of a DNA mycovirus and its use as a natural fungicide. Proceedings of the National Academy of Sciences 110:1452-1457.

32.Zhang L., Fu Y., Xie J., Jiang D., Li G. and Yi X. 2009. A novel virus that infecting hypovirulent strain XG36-1 of plant fungal pathogen Sclerotinia sclerotiorum. Virology journal 6:96-105. 